\title{
The Influence of Using Social Media as a Learning Platform by Bilingual and Multilingual Learners on English Speaking Skills
}

\author{
Porawe Poramathikul'), Nakibah Arwedo2), Innas Abdulhakim³), \\ Pitchayaporn Wattanaruwangkowit4) \\ 1), 2), 3), 4)Mae Fah Luang University, Chiang Rai,Thailand \\ Nakibah.arw@gmail.com
}

\begin{abstract}
This study aims to discover the influences of using social media on the English speaking skills. To fulfill this study's goal, data was collected using questionnaires, selfassessment, and speaking tests. Participants of the study were 20 bilinguals and multilingual of any two or more languages that are currently studying English as a foreign language (EFL) at the university level in Thailand. The result from speaking proficiency self-assessment shows the perception of bilinguals and multilingual who perceived that they can speak English fluently than accurately. The average score of the self-assessment is 5.59 out of 9. The standard deviation (S.D.) of their score is 1.46. This score shows that the participants consider themselves as competent users of English according to the description from British Councils (2012). Only eight out of 20 or 40 percent of the participants think that they have reached the level of capable users of the English, while the other 60 percent of participants think that they have not reached that level. From this study, it has been found that bilingual and multilingual speakers often use social media for educational purposes.
\end{abstract}

Keywords: social media, speaking skills, bilingual and multilingual

Citation APA Style: Poramathikul, P., Arwedo, N., Abdulhakim, I., \& Wattanaruwangkowit, P. (2020). The Influence of Using Social Media as a Learning Platform by Bilingual and Multilingual Learners on English Speaking Skills. English Language in Focus (ELIF), 2(2), 111-122.

INTRODUCTION

$\mathrm{N}$

owadays, English plays a dominant role as an international language for communication across the globe, and the language of communication on the Internet is mainly based on English. "As of April 2019, English was the most popular language online, representing 25.2 percent of worldwide internet users" (Clement,
2019). Because of the majority use of English in the Internet world, English learners have been learning the language through social networks, podcasts, and blogs. English teachers should be creative in teaching English and should upgrade the method (Rizqiningsih \& Hadi, 2019).

Moreover, the traditional bookoriented learning approach changed learning the language from social media 
(Malerba \& Barcelona, 2015). Malerba \& Barcelona (2015) has concluded that social networks allow language learners to cross-geographical barriers and help English language learners to interact with native speakers and to access distant places and cultures. Al Qahtani (2018) stated that social networks have powerful information-sharing and collaborative opportunities for EFL learners.

Several social media provide the users to communicate orally with them such as Facebook, WhatsApp, Line, etc. This provides great opportunities to practice speaking with native speakers around the world. According to Kay, Kai, Jun, \& Hor (2014), the use of homophones on the internet could affect users' speaking skills. Moreover, social media also plays a significant role in language acquisition of children. Children's language acquisition happens when children naturally interact with more language-proficient adults (Rudd \& Lambert as cited in Cabrera, 2018). According to Pearson (2007), the proficiency of bilinguals in children depends on how much the children are exposed to other languages which social media is the key to create the perfect environment. It can be concluded that social media encourages the development of bilingualism in children.

Hong-Nam \& Leavell (2007) found that the capabilities of learning languages of bilinguals tend to be better than monolinguals, and this might have an impact on learners to have a greater potential for acquiring knowledge of a third language. The preferred learning styles of young people around the world who want to learn English have changed because of the existence of the Internet (Dhanya, 2016). Social Media is believed to provide better opportunities and environments for learning. Many platforms allow oral two-way communication and are available for practicing speaking skills with real native speakers around the world.

Children nowadays are familiar with the Internet since their very young age, and the Internet and social media are unhealthy if it is overused. OECD (2018) reported that children spend more than two hours online on weekdays and more than three hours on weekends on average. The study has also found the impact of the Internet to be positive on mental wellbeing if it is used a little bit; on the other hand, excessive use has been found to have a negative impact on mental wellbeing and to be associated with poorer sleep. Lau (2017) indicated that the purpose of using social media could affect a student's performance. If social media were only used for nonacademic purposes, it could have a negative impact on users.

Ravezza, Hambrick, \& Lau (2017) found that using social media for nonacademic purposes was associated with a negative effect on classroom performance. On the other hand, there is some evidence about the benefits of using social media in learning; for instance, Twitter could use curricular discussion that affects positively on college students' grades. Even though positive and negative impacts of the internet and the use of social media on education has been found, the use of social media may contribute to the good learning of English speaking proficiency because of its useful functions to access 
information and to communicate with people around the world easily.

Normally, the terms of bilingual and multilingual speakers are understood as who are equally expert in two languages or more. However, this research investigated who may not be equally expert in every language they speak. The participants chosen have been studied the language(s) for some time, and they can at least use the language(s) to communicate in daily life effectively with native speakers.

This study comprises six research objectives.

1. To survey how often bilinguals or multilingual use social media for general and educational purposes

2. To find out which platforms of social media bilinguals or multilingual mostly use for general and educational purposes

3. To discover bilinguals or multilingual' perceptions of their speaking proficiency in terms of fluency and accuracy

4. To find out whether or not using social media could influence the speaking skills of bilinguals or multilingual

5. To discover whether there is a relationship between students' perceptions, their speaking proficiency scores, and the use of social media

6. To discover the speaking proficiency of bilingual or multilingual EFL learners

To achieve the aforementioned research objectives, there are six research questions.

1. How often bilingual and multilingual speakers use social media for general and academic purposes, and which platforms of social media they mostly use for each purpose?

2. Which platforms of social media bilinguals or multilingual mostly use for general and educational purposes?

3. How do bilinguals and multilingual perceive their English speaking skills in terms of fluency and accuracy?

4. How social media influence the speaking skills of bilinguals or multilingual?

5. Is there a relationship between students' perceptions, their speaking proficiency scores, and the use of social media?

6. What is the speaking proficiency of bilingual and multilingual learners?

\section{Bilingualism/ Multilingualism and their Speaking Problems}

Bilingual is considered as the equal expertise of two languages or the use of at least two languages by the same individual (Mackey, 1962); on the other hand, bilingualism is regarded as a complex phenomenon which is influenced by various factors: age, situation, environment, and first language (Gottardo as cited in Khiyavi, Rostami, \& Gholami, 2016). According to $\mathrm{Li}$ in Cenoz (2013), a multilingual speaker is defined as an individual who can communicate in more than one language in both active way, speaking and writing; and passive way, listening and reading. Thus, who are bilinguals and multilingual? Many factors cause children to become bilingual speakers: communicating the traditional language of children's family, immigrating to another country, learning another 
language than the mother tongue, or temporarily living in another country (Butler, 2012).

The study, however, found that being bilingual or monolingual is no longer required to have a perfect mastery in two or more languages. This could refer to balanced and unbalanced multilingual. Balanced multilingualism is when a speaker has an equal expertise in both or more languages while unbalanced multilingualism is when a speaker has different levels of expertise in different languages (Skutnabb-Kangas \& McCarty as cited in Cenoz, 2013). In addition to its definition, Green (1996, 1998) in Butler (2012)claimed that when bilingual speakers are in the mode of producing more than one language, they can choose which language to speak in situations according to context, so it is suggested that their use of languages are organized in a different subsystem that is activated to different extents. Hong-Nam \& Leavell (2007) also claimed that the habits of communicating dual languages to survive could automatically influence Korean-Chinese bilingual students' English proficiency.

Furthermore, Valencia and Cenoz (1993) in Khiyavi et al (2016) claimed that bilingual students tend to be superior in learning a foreign language than monolingual students. In addition, according to Qasimnejad \& Hemmati (2014), bilingual Turkish-Persian students seem to achieve the goals of learning languages more than monolingual Persians. Even though they can speak many languages, they also have particular speaking problems and language is supposed to be said not written so that it becomes a form of communication between humans (Yolanda \& Hadi, 2019). Language course guide (2019) in Cenoz\&Gorter (2011)stated that the bilinguals and multilingual face several challenges when they are learning the target language such as language fluency delay, literal interpretation, and code-switching. Codeswitching has been regarded as the most unique performance of bilingual speakers. There is no better behavioral sign which claims that a speaker is bilingual than when they employ two languages simultaneously to interact in a particular society.

Bialystok, Craik, \&Luk (2012) in Heredia \& Altarriba (2001) stated that since there are two languages in the bilingual person's brain, it may lead to speaking skills to be weaker than monolingual speakers. Moreover, a bilingual person often faces language mixing that the word or phrase in one language was substituted by another language while speaking. The reasons of this problem is that they cannot retrieve a correct word because they are unable to remember the word that is not frequently used; therefore, switching to the second language is easier and faster than retrieving the word (Lederberg \& Morales as cited in Heredia \&Altarriba, 2001).

For this reason, stuttering, word choice, and word order inaccuracy may slightly have occurred during the codeswitching (Grosjean as cited in Serras, Tutora, \& Hunter, 2017). For example, Spanish-English language has a different structure of noun and adjective positions in which the noun precedes the adjective in Spanish while the adjectives precede the noun in English; thus, the structures 
will be incorrect if they speak one language in another language sentence (Heredia \& Altarriba, 2001). Additionally, most studies found that bilinguals have smaller productive and receptive vocabulary than monolinguals; therefore, bilingual learners know fewer words of semantic category when compared to their age-matched monolinguals (Gollan, Montoya, \& Werner, 2002).

\section{Language Acquisition of Bilinguals and Multilingual}

For the second language acquisition of bilinguals, age and environment are the important factors to influence their language acquisition. Age plays a major role in the variability of language acquisition of bilingual and multilingual speakers. Children at a young age are better at learning a second language than adults (Butler, 2012). Another important factor is the environment. The environment in which occasions take place also influences language learning. A supportive environment effects directly to learners' language competency. Once learners are put into an environment that supports their second language learning, they will eventually learn and acquire the language (Sudsa-ard, 2013). The more chances or opportunities to use another language are better for learners to acquire a second language (Malerba, 2011).

The Influence of Social Media on Second Language Acquisition

Since their opening, social media platforms such as Youtube, Facebook, Twitter, and Instagram attracted millions of users, and many people surf these platforms as their daily basics. Most platforms help strangers connect based on shared interests or activities (Boyd \& Ellison, 2007). The definition of social media according to the oxford dictionary is "Websites and applications that enable users to create and share content or to participate in social networking". The other researcher defined social media as an online platforms sites that is based on user participation and user-generated content (Obar \& Wildman, 2015).

In general, the use of social media as a learning platform could provide a better learning environment and help EFL students to be more confident and eager to learn English. According to AlQahtani (2018), there are many applications or sites of social media that are normally used by university EFL learners such as Facebook, WhatsApp, Twitter, and LinkedIn, etc, and the use of social media influences the way they search, manage and use information. Chen (2011) in Yen, Hou, \& Chang (2015) found that interaction with computers provides a less intimidating and more comfortable situation than the interaction with humans. Lin et al (2016) in Sun et al (2017) reviewed thousands of users' opinions of a leading language learning social network site named Livemocha and discovered that the majority of users felt more motivated, confident, and comfortable texting online than in person after using Livemocha.

Sun and Yang (2015) in Sun et al (2017) used YouTube and Facebook to combine service-learning with an EFL speaking course and proclaimed the distinguished gains in speaking and pronunciation and the improved confidence of students. Moreover, it is certain from the results of the previous 
research studies and practical observations of many active users of Facebook, WhatsApp and other applications or sites of social media that have a positive outcome on the English learning proficiency at the university level (Khan \&Ayaz, 2016).

It has been found that the use of Facebook and Skype that provides the platforms for oral two-way communication could be effective as learning tools. The social Role-playing strategy was applied in the class of EFL students as a case study in Taiwan to improve their writing and speaking skills through the use of Facebook and Skype as learning tools (Yen et al., 2015). The results indicate that the use of Facebook is effective for enhancing speaking and writing skills, and the use of Facebook together with the role-playing strategy is proved to be very effective for EFL teaching strategy. Skype was found to have a negative correlation on the learning effect. The reason might be because students were enthusiastic to express their idea rather than focusing on the correctness. While social media is used among English learners and found to be beneficial to English learning, the study on how bilinguals and multilingual use social media has not been described to date. Thus, this research investigated how often, through which platforms, and for what purposes bilinguals and multilingual use social media.

\section{RESEARCH METHODOLOGY}

$\mathrm{T}$ his study aims to discover the influences of using social media on the English speaking skills. To fulfill this study's goal, data was collected using questionnaires, self-assessment, and speaking tests. This section explains the components of data collection including setting and participants, instruments, analysis, and procedures. Participants of the study were 20 bilinguals and multilingual of any two or more languages that are currently studying English as a foreign language (EFL) at the university level in Thailand. Accordingly, the participants for this study were selected purposively that they must be able to speak at least two languages not including English. They might not be extremely fluent in every language they know, but they must be able to communicate in daily life effectively with the natives of that language. Moreover, the participants selected are studying at the university level (bachelor's degree).

\section{FINDING AND DISCUSSION}

rom this study, bilingual and
multilingual speakers often use
social media for educational purposes and always use social media in daily life. In self-assessment, they tend to perceive their English speaking proficiency to be more fluent than accurate. This simply means that social media doesn't have a significant influence on their English speaking overall, but their English speaking proficiency is likely to be contributed by other factors than social media. Furthermore, the participants tend to be underestimated about their speaking skills and still want to improve themselves. 


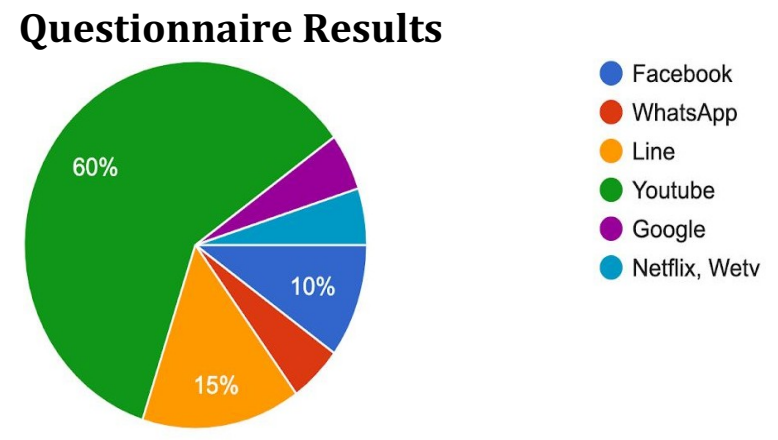

Figure 1. Social media platforms, which are used for educational purposes by bilinguals and multilingual

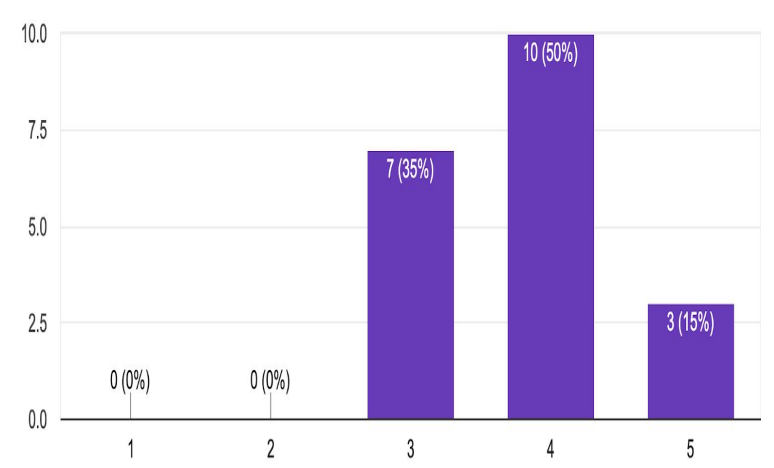

Figure 2. How often bilinguals and multilingual use social media platform for educational purposes (1=Never, $2=$ Rarely $3=$ Sometimes, $4=$ =ften, $5=$ =Always)

From Figures 1 and 2, the average results show that the participants often use social media for educational purposes, and the most used platform is Youtube (twelve out of twenty).

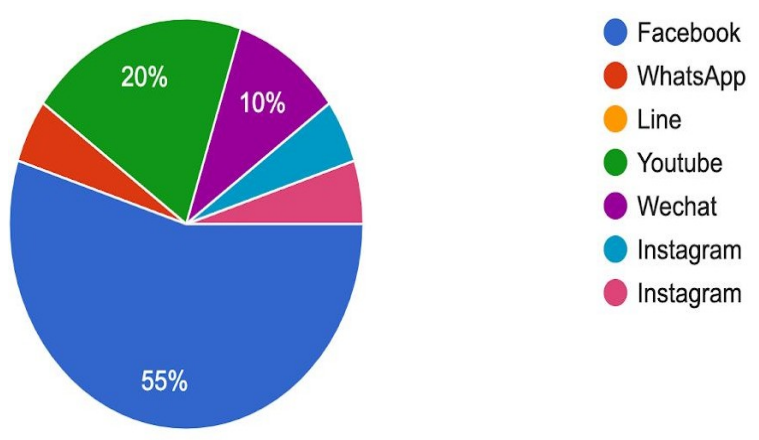

Figure 3. Social media platforms that are mostly used in daily life activities by bilinguals and multilingual
Figure 4. Social media platforms that are

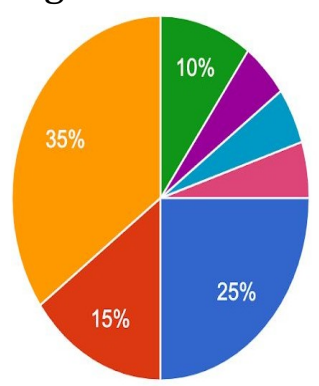

Facebook

WhatsApp

Line

Youtube

Skype

Viber, Skype, WhatsApp

Wechat

mostly used in daily life for twoway oral communication by bilinguals and multilingual

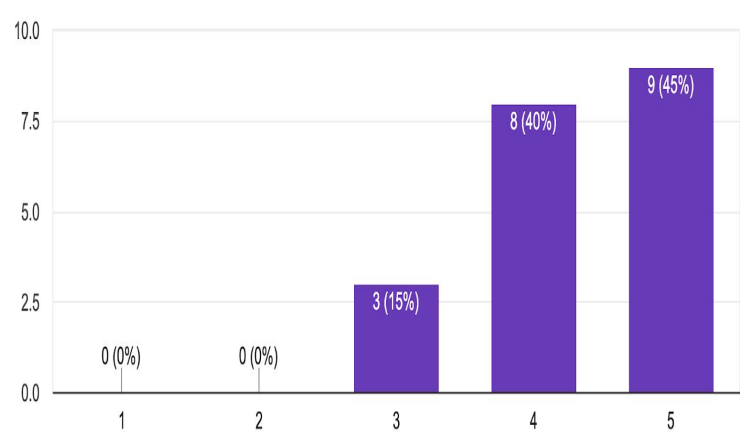

Figure 5. How often bilinguals and multilingual use social media in daily life (1=Never, 2=Rarely, $3=$ Sometimes, $4=0$ ften, $5=$ Always)

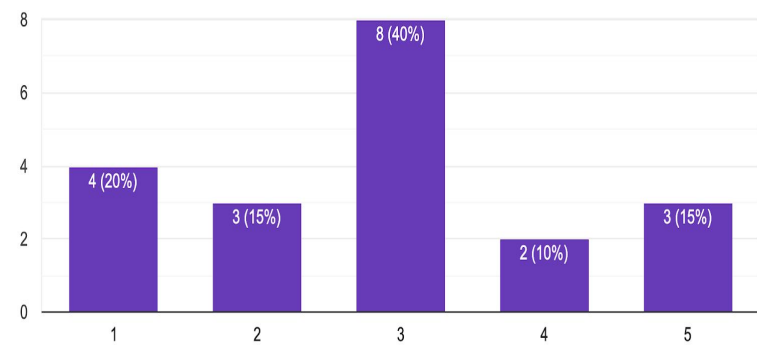

Figure 6. How often bilinguals and multilingual use social media to talk with native speakers around the world (1=Never, 2=Rarely, $3=$ Sometimes, $4=$ Often, $5=$ Always)

From figure 3-6, they often use social media for general purposes, and the most used platform in daily life activities is Facebook (eleven out of twenty). They always use social media in daily life, but they only use social media to talk with native speakers sometimes. 


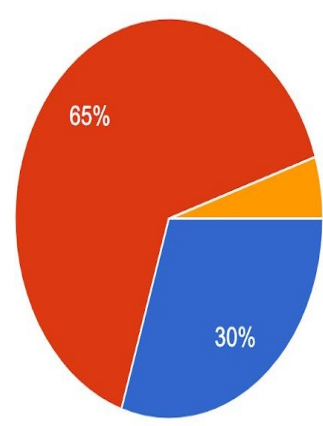

Figure 7. Languages used to communicate through social media by bilinguals and multilingual

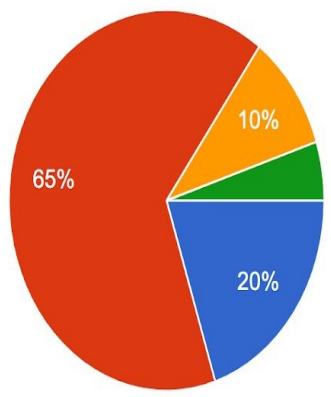

English

Your First language

Thai

Kelatanese Malay

Figure 8. Languages used to orally communicate through social media by bilinguals and multilingual

Furthermore, from figure 7-8, most of the participants use their first language to communicate through social media (thirteen out of twenty) and orally communicate through social media (thirteen out of twenty).

It shows that they perceive the level of effectiveness of using social media for educational purposes and improving their English speaking skills as above average. On the other hand, the result shows that their perception towards the effectiveness is contradicted to their use of social media to improve English-speaking skills because English is not the language they mostly use in social media. Accordingly, the English speaking skills of bilingual and multilingual speakers are not significantly influenced by the use of social media. It can be concluded that the main factors contributed to the participants' English speaking proficiency possibly come from something else than social media, such as their mother tongue, their selfmotivation or inspiration, their excellence in any other language.

Speaking Proficiency Self-assessment Result

The result from speaking proficiency selfassessment shows the perception of bilinguals and multilingual who perceived that they can speak English fluently than accurately. The average score of the self-assessment is 5.59 out of 9. The standard deviation (S.D.) of their score is 1.46. This score shows that the participants consider themselves as competent users of English according to the description from British Councils (2012). Only eight out of 20 or 40 percent of the participants think that they have reached the level of capable users of the English, while the other 60 percent of participants think that they have not reached that level. However, eleven out of twenty participants evaluated themselves lower than their level evaluated using the speaking test, and three of them evaluated themselves higher than their level evaluated using the speaking test. It is possible that most of them are humble about their true speaking skills and still want to improve themselves more.

\section{Speaking Test Results}

The speaking test consisted of ten general questions about participants' study from 'IELT Speaking Part 1 Topics \& Questions' (Elizabeth, 2014). The participants answered the questions in 
speaking. After the answers were recorded, it was evaluated according to a public version of IELT Speaking Band Descriptors (British Council, 2012). The average score from the speaking test of 20 participants is 5.89 out of 9 which means that they are at the level of competent users of English on average. It implies that they have not reached the level of good users yet according to the description from the British Council (2012). The standard deviation (S.D.) of their score is 1.93. The participants at the competent level or above are equal to 55 percent of all participants. The other 45 percent of the participants are varied at an extremely limited level to the level of modest users.

\section{CONCLUSION}

$\mathrm{F}$ rom this study, it has been found that bilingual and multilingual speakers often use social media for educational purposes. According to the results of the questionnaire, it indicated that bilinguals and multilingual mostly use YouTube (twelve out of twenty) for academic purposes, and the platform that is mostly used for general purposes is Facebook (thirteen out of twenty). They always use social media in daily life, but they only sometimes use social media to talk with native speakers. Moreover, they mostly use social media in their first language rather than English. This signifies that social media doesn't have a significant influence on their English speaking overall, but their English speaking proficiency is likely to be contributed by other factors than social media. However, the results of the speaking test, it can be noticed that all participants who always use social media to communicate orally with the native speakers of English (three out of twenty) achieved the level of very good users of English or above. It shows that social media may contribute to the speaking skills of English learners if they always use social media to communicate with native speakers of English.

When coming to speaking proficiency self-assessment, participants tend to perceive their English speaking proficiency to be more fluent than accurate. Eleven out of twenty of the participants underrated their speaking proficiency comparing their selfassessment to their results of the speaking test. It may signify that they tend to underestimate their speaking ability and still want to improve themselves. Even though they perceive the effectiveness of socialmediatohelpthemimprovetheirEngl ishspeakingproficiencytobeaboveaverage , there is not a significant relationship between their perceptions toward its effectiveness, their speaking proficiency scores, and their use of social media.

However, a limitation should be noted in this research that there are some conflicting answers found in the results. Some questions used in self-assessment are not clear between fluency and accuracy. The participants may be confused by those questions; therefore, some of their answers are not covered. Accordingly, the misleading questions are cut out from the analysis.

\section{REFERENCES}

AlQahtani, N. A. (2018). The Effect of Social Networks on the Improvement of Saudi EFL Students. Journal of Humanities \& Social Sciences, 2(8), 137-150. Retrieved 
from https://doi.org/10.26389/ AJSRP.N130618.

Boyd, Danah M., \& Ellison, N. B. (2007). Social Network Sites: Definition, History, and Scholarship. Journal of Computer-Mediated Communication, 13(1), 210-230. https://doi.org/10.1111/j.10836101.2007.00393.x

British Council. (2012). How IELTS is assessed | Take IELTS. Retrieved September 26, 2019, from https://takeielts.britishcouncil.org/t each-ielts/testinformation/assessment

$\begin{array}{llll}\text { Butler, } & \text { Y. } & \text { G. }\end{array}$ Bilingualism/multilingualism and second-language acquisition. In T. K. Bhatia \& W. C. Ritchie (Eds.), The Handbook of Bilingualism and Multilingualism (Second Edition, pp. 109-136). Chichester, UK: John Wiley \& Sons, Ltd. https://doi.org/10.1002/97811183 32382

Cabrera, L. (2018). Impact of Social Media in English Language Learning: Utilizing S.W.O.T Analysis. Retrieved from

https://www.researchgate.net/publ ication/327822150

Cenoz, J, \& Gorter, D. (2011). Focus on Multilingualism: A Study of Trilingual Writing. The Modern Language Journal, 95(3), 356-369. https://doi.org/10.1111/j.15404781.2011.01206. $\mathrm{x}$

Cenoz, Jasone. (2013). Defining Multilingualism. Annual Review of Applied Linguistics. Cambridge University Press. https://doi.org/10.1017/S0267190 51300007X
Clement, J. (2019, June 22). Internet: Most Common Languages Online 2019. Retrieved September 26, 2019, from https://www.statista.com/statistics /262946/share-of-the-mostcommon-languages-on-the-internet/

Dhanya, G. (2016). Influence of Social Media on English Language learning. Journal of English Language and Literature (JOELL), 3(1), 105-110. Retrieved from http://joell.in/wpcontent/uploads/2016/03/INFLUE NCE-OF-SOCIAL-MEDIA.pdf

Elizabeth. (2014). IELTS Speaking Part 1 Topics \& Questions. Retrieved September 26, 2019, from https://ieltsliz.com/ielts-speakingpart-1-topics/

Gollan, T. H., Montoya, R. I., \& Werner, G. A. (2002). Semantic and Letter Fluency in Spanish-English Bilinguals. Neuropsychology, 16(4), 562-576. Retrieved from http://www.ncbi.nlm.nih.gov/pubm ed/12382994

Gwendolyn. (2016, April 12). How to Estimate Your IELTS Band Score Magoosh IELTS Blog. Retrieved September 26, 2019, from https://magoosh.com/ielts/aboutielts-exam/ielts-results/how-toestimate-your-ielts-band-score/

Heredia, R. R., \& Altarriba, J. (2001). Bilingual Language Mixing: Why Do Bilinguals Code-Switch? Current Directions in Psychological Science, 10(5), 164-168. https://doi.org/10.1111/14678721.00140

Hong-Nam, K., \& Leavell, A. G. (2007). A Comparative Study of Language Learning Strategy Use in an EFL 
Context: Monolingual Korean and Bilingual Korean-Chinese University Students. Asia Pacific Education Review, 8(1), 71-88. https://doi.org/10.1007/BF030258 34

Kay, C. Y., Kai, F. J., Jun, G. K., \& Hor, W. Y. (2014). The Impact of Social Network on English Proficiency Among Students in University Tunku Abdul Rahman (Utar) Sungai Long, Malaysia. Final Year Project, UTAR. Retrieved from http://eprints.utar.edu.my/1684/

Khan, M. S., \& Ayaz, M. (2016). Effect of Social Media on Enhancement of English Learning Proficiency at University Level in Khyber Pakhtunkhwa. Journal of Humanities and Social Sciences, 2(2), 71-84. Retrieved from http://www.iaset.us

Khiyavi, B. M., Rostami, G., \& Gholami, H. (2016). Effects of Bilingualism and Monolingualism on Iranian EFL Learner s' performance on Reading Comprehension Test. Journal of Applied Linguistics and Language Research, 3(4), 225-233. Retrieved from

https://www.semanticscholar.org

Lau, W. W. F. (2017). Effects of Social Media Usage and Social Media Multitasking on the Academic Performance of University Students. Computers in Human Behavior, 68, 286-291.

https://doi.org/10.1016/j.chb.2016. 11.043

Mackey, W.. (1962). The description of Bilingualism. In W. Li (Ed.), The bilingualism reader (pp. 25-26). New York: Routledge.

Malerba, M. L. (2011). Social Networking and Informal Second Language Learning in Livemocha and Busuu Online Communities. University Oberta de Catalunya, Barcelona, Spain.

Malerba, M. L., \& Barcelona, C. (2015). Social Networking in Second Language Learning: Informal Online Interactions. Retrieved from https://www.semanticscholar.org/

Obar, J. A., \& Wildman, S. S. (2015). Social Media Definition and the Governance Challenge: An Introduction to the Special Issue. Telecommunications Policy, 39(9), 745-750.

https://doi.org/10.2139/ssrn.2647 377

OECD. (2018). Children \& Young People's Mental Health in the Digital Age Shaping the Future. Retrieved from https://www.oecd.org/els/healthsystems/Children-and-YoungPeople-Mental-Health-in-the-DigitalAge.pdf

Pearson, B. Z. (2007). Social Factors in Childhood Bilingualism in the United States. Applied Psycholinguistics, 28(3), 399-410. https://doi.org/10.1017/S0142716 40707021X

Qasimnejad, A., \& Hemmati, F. (2014). Investigating the Language Learning Strategies Used by Iranian Monolingual (Persian) and Bilingual (Persian_Turkish)Speakers as EFL Learners. Procedia - Social and Behavioral Sciences, 136, 26-30. https://doi.org/10.1016/j.sbspro.20 14.05.281

Rizqiningsih, S., \& Hadi, M. S. (2019). Multiple Intelligences (MI) on Developing Speaking Skills. English 
Language in Focus (ELIF), 1(2), 127-

136. Retrieved from https://jurnal.umj.ac.id/index.php/

ELIF

Serras, M., Tutora, R., \& Hunter, J. (2017). The Bilingual World: a Study on Bilingualism and Its Cognitive Effects. Barcelona.

Sudsa-ard, S. (2013). The Learner Factors: Guide for Successful Language Learning. Thammasat Review, 16(3), 41-52. Retrieved from https://sc01.tcithaijo.org/index.php/tureview/artic le/view/40730

Sun, Z., Lin, C. H., You, J., Shen, H. Jiao, Qi, S., \& Luo, L. (2017). Improving the English-Speaking Skills of Young Learners through Mobile Social Networking. Computer Assisted
Language Learning, 30(3-4), 304324.

https://doi.org/10.1080/09588221. 2017.1308384

Yen, Y. C., Hou, H. T., \& Chang, K. E. (2015). Applying Role-Playing Strategy to Enhance Learners' Writing and Speaking Skills in EFL Courses Using Facebook and Skype As Learning Tools: A Case Study in Taiwan. Computer Assisted Language Learning, 28(5), 383-406. https://doi.org/10.1080/09588221. 2013.839568

Yolanda, D., \& Hadi, M. S. (2019). Using Puppet Games in Teaching Speaking for Tenth Graders of Senior High School. English Language in Focus (ELIF), 2(1), 1-8. Retrieved from https://jurnal.umj.ac.id/index.php 